\title{
Assessment of serum cystatin $C$ in the early detection of type 2 diabetic nephropathy in Cotonou, Benin
}

\author{
Jacques Vigan', Séraphin Ahoui ${ }^{2}$, Bruno Léopold Agboton', Kossi Akomola Sabi ${ }^{3}$, Weu Mélanie Tia ${ }^{4}$, FB Rodolphe Tchaba', \\ François Djrolo
}

'University Clinic of Nephrology and Haemodialysis, National Teaching Hospital of Cotonou, Benin; '2Department of Nephrology, Borgou University Teaching Hospital, Parakou, Benin; ' Department of Nephrology, Sylvanus Olympio University Hospital Center, Lomé, Togo; ${ }^{4}$ Department of Nephrology, Teaching Hospital of Yopougon, Côte d'Ivoire; ${ }^{5}$ Endocrinology and Metabolism University Clinic of National Teaching Hospital of Cotonou, Benin.

\section{ABSTRACT}

Introduction: Diabetic nephropathy is a frequent and dreaded complication of diabetes mellitus. The purpose of this work was to study the role of serum cystatin $C$ in the early detection of diabetic nephropathy among type 2 diabetic patients.

Methods: This was a cross-sectional study conducted in Cotonou over a period of six months. Blood samples were tested at the regional food safety testing analysis laboratory. Type 2 diabetic patients older than 15 years, who gave their informed consent, were included in the study. Patients with proven proteinuria, acute kidney injury, haematuria, a positive urine test for nitrite, or reduced glomerular filtration rate $<60 \mathrm{~mL} / \mathrm{min} / 1.73 \mathrm{~m}^{2}$ were excluded from the study. All patients were subjected to serum cystatin $C$ and microalbuminuria assays.

Results: Eighty-eight patients were included in the study. Their average age was $50.7 \pm 9.6$ years and the male to female ratio was 1.4:I. Twenty-four-hour microalbuminuria was positive in 53 (60\%) cases whereas serum cystatin $\mathrm{C}$ tested positive in only 2 cases. Sensitivity and specificity tests applied to cystatin C showed very low sensitivity (4\%) with a positive predictive value of $100 \%$ and high specificity (100\%) with a negative predictive value of $41 \%$. Conclusions: When compared with 24-hour microalbuminuria, serum cystatin $C$ assay was not sensitive enough to prove suitable for screening for diabetic nephropathy. Serum cystatin C would therefore not be useful for the early detection of nephropathy among type 2 diabetic patients.

Keywords: Benin; cystatin C; CKD screening; microalbuminuria; diabetic nephropathy.

\section{INTRODUCTION}

Diabetic nephropathy (DN) is a form of progressive chronic kidney disease and one of the most frequent and dreaded complications of diabetes mellitus [I]. This complication could be prevented by appropriate treatment following early detection, particularly among type 2 diabetic patients. Early detection is often based on 24hour microalbuminuria bioassays [2] and this is of great therapeutic and prognostic importance. However, in some cases, kidney disease is not detected through this test and, therefore, efforts have been made to find better biomarkers [3].

Some biomarkers have been developed to estimate the glomerular filtration rate (GFR) and detect declining kidney function. However, there is still a lack of simple tools to detect trends in renal function over time, when the GFR is normal or high [3]. Cystatin C is a lowmolecular weight endogenous protein, produced at a steady rate by nucleated cells and eliminated from the

Received 01 August 2017; accepted 06 August 2018; published 23 February 2019. 
body by glomerular filtration and subsequent proximal tubular reabsorption and degradation [4]. It is a potentially useful biomarker when the glomerular filtration rate is still normal or only slightly reduced $[5,6]$.

Several equations have been established to estimate the GFR based on serum cystatin C [7-10]. The predominance of these formulae over those derived from the Modification of Diet in Renal Disease (MDRD) study is not proven $[10,1 \mathrm{I}]$ among type 2 diabetic patients. In about 20 diabetic patients, Rigalleau et al. observed a significant correlation between glomerular filtration rate determined through radioisotope methods and GFR estimated using cystatin C-based equations [12]. There is less bias with cystatin C-based equations than with the MDRD equation. Indeed, they are more useful for follow-up of renal function as suggested by a longitudinal study on type 2 diabetes [3]. Cystatin $C$ offers improvements in the estimation of the GFR among diabetic patients, but requires standardization $[|3| 4$,$] .$

Among type 2 diabetic patients, cystatin $\mathrm{C}$ as a biomarker has been compared to creatinine-based methods to estimate GFR, but very few studies have compared it to microalbuminuria for the detection of DN. Our overall objective was to study the role of serum cystatin $C$ in the early detection of diabetic nephropathy among type 2 diabetic patients, using microalbuminuria assessed on 24hour urine collection as our reference standard.

\section{METHODS}

This cross-sectional study was conducted over a period of six months, from April to September 2014, at the Cotonou Insulin Bank, where patient recruitment as well as blood and urine sampling were undertaken. Samples were handled at the Biochemical Department of the regional food safety testing analysis laboratory at the Regional Institute of Industrial Engineering, Biotechnology and Applied Sciences (IRGIB-Africa).

We included all type 2 diabetic patients aged above 15 years who consented to participate in the study. We excluded all patients with proven proteinuria, haematuria, positive urine test for nitrite, reduced GFR $<60 \mathrm{~mL} /$ $\mathrm{min} / 1.73 \mathrm{~m}^{2}$, congestive heart failure, prostate disease, malignancy or infection. Each patient was given a simplified and schematic explanation of the 24-hour urine collection procedure.

All patients were subjected to 24-hour microalbuminuria and serum cystatin $C$ measurement. Microalbuminuria was determined by immuno-chromatography on freshly collected urine. The normal value is less than $30 \mathrm{mg} / 24 \mathrm{~h}$ and microalbuminuria was considered present when it was $\geq 30$ $\mathrm{mg} / 24 \mathrm{~h}$ and $\leq 300 \mathrm{mg} / 24 \mathrm{~h}$ on two samples obtained one month apart. The serum cystatin $C$ concentration was measured through sandwich ELISA. Serum samples were stored at $-20^{\circ} \mathrm{C}$ and measurements made in a single batch. The normal value of serum cystatin $C$ is between 7.8-500 $\mathrm{ng} / \mathrm{mL}$. It is considered as raised when $\geq 500 \mathrm{ng} / \mathrm{mL}$.

In addition, socio-demographic variables (age, gender, profession, place of origin), history (hypertension, family history), clinical data (body mass index, weight) and laboratory data (blood glucose and serum creatinine) were all recorded.

The data were entered, processed and analysed using SPSS 16.0. Sensitivity, specificity, positive predictive value (PPV) and negative predictive value (NPV) of serum cystatin C were calculated using the microalbuminuria test as the gold standard. Statistical significance was set at $<5 \%$ and $95 \%$ confidence intervals were calculated.

\section{RESULTS}

The study population included 88 patients. Their sociodemographic characteristics are summarized in Table I. Patients' ages ranged from 21-75 years, with a mean age of $50.7 \pm 9.6$ years. Women comprised $58 \%$ and all the patients were urban residents.

Diabetic nephropathy, as diagnosed by the presence of microalbuminuria, was present in 53 of the 88 patients (60.2\%). Elevated cystatin C concentrations were present in 2 patients (2.3\%); these patients also demonstrated microalbuminuria. The sensitivity of the cystatin $C$ test was $3.8 \%$, and the specificity 100\%. The PPV was $100 \%$ and the NPV $40.7 \%$.

\begin{tabular}{|c|c|c|}
\hline & Total $(n=88)$ & Percentage (\%) \\
\hline \multicolumn{3}{|l|}{ Age } \\
\hline$<45$ & 20 & 22.72 \\
\hline $45-50$ & 21 & 23.86 \\
\hline $50-55$ & 18 & 20.45 \\
\hline$\geq 55$ & 29 & 32.95 \\
\hline \multicolumn{3}{|l|}{ Gender } \\
\hline Male & 37 & 42.00 \\
\hline Female & 51 & 58.00 \\
\hline \multicolumn{3}{|l|}{ Place of residence } \\
\hline Cotonou & 88 & 100.00 \\
\hline \multicolumn{3}{|l|}{ Level of education } \\
\hline Completed school & 26 & 29.50 \\
\hline Primary education & 17 & 19.30 \\
\hline Secondary education & 33 & 37.50 \\
\hline Tertiary education/University & 12 & 13.60 \\
\hline
\end{tabular}




\section{DISCUSSION}

A large proportion of our study population had diabetic nephropathy as assessed by our gold standard, microalbuminuria. However, the cystatin C-based test to estimate GFR had very low sensitivity for detecting the affected patients and therefore cannot be used for the early diagnosis of diabetic nephropathy when the GFR would be expected to be near-normal, or even elevated.

Diabetic patients should have annual tests for microalbuminuria as recommended by the Diabetes Association and the National Kidney Foundation [15-17]. Microalbuminuria is a risk marker for both cardiovascular disease and renal dysfunction among type 2 diabetic patients [15, 18]. In 2015, Agboton et al. reported a 24hour microalbuminuria frequency of $47.5 \%$ in type 2 diabetic patients in southern Benin [19]. The frequencies of various hospital-based studies range from $10.3 \%$ to $57.3 \%[18,20]$.

Ali et al. reported a prevalence of $16.1 \%$ among type 2 diabetic patients in Iraq [2I], whereas Berrada et al. reported a frequency of 65\% [22]. Other studies from Pakistan, India and Tanzania reported prevalences ranging from $20 \%$ to $61 \%$ [23-25]. In a literature review on the prevalence of diabetic nephropathy among type 2 diabetic patients in some Arab countries, Aldukhayel reported a prevalence ranging from $1.2 \%$ to $61.2 \%$ [26].

Of our 88 diabetic patients, serum cystatin $C$ was raised amongst only two. Our study excluded patients with GFR $<60 \mathrm{~mL} / \mathrm{min} / 1.73 \mathrm{~m}^{2}$ and also included very few elderly patients. In studies where patients with all levels of renal function are included, the prevalence of nephropathy based on cystatin C would be expected to be much higher [27].

Compared to creatinine, cystatin $C$ has been reported in some studies to be a more sensitive marker for the estimation of GFR among type 2 diabetics [14], whereas other studies found it to be less sensitive in detecting early kidney failure among diabetic patients [28]. Wang et al. have shown that serum cystatin $C$ was positively correlated with microalbuminuria and increased with the progression of diabetic nephropathy [29]. Furthermore, Mueller et al. demonstrated that cystatin $C$ does not detect acute changes of GFR and is not useful in assessing renal functional reserve [30].

\section{CONCLUSIONS}

Our study found that the ability of serum cystatin C measurements to diagnose diabetic nephropathy at an early stage was poor. It therefore cannot be recommended as a screening test in those patients who would be expected to have normal or near-normal GFR.

\section{REFERENCES}

I. Železníková V, Vedralová M, Kotrbová-Kozak A, Zoubková H, Cerná M, Rychlík I. The intron 4 polymorphism in the calcium-sensing receptor gene in diabetes mellitus and its chronic complications, diabetic nephropathy and non-diabetic renal disease. Kidney Blood Press Res. 2014; 39(5):399-407.

2. Dhia RB, Hellara I, Harzallah $O$, Neffati F, Khochtali I, Mahjoub S, et al. Evaluation de la fonction rénale chez le diabétique de type 2: calcul des clairances ou cystatine C? Ann Biol Clin (Paris). 2012; 70(3):287-294.

3. Perkins BA, Nelson RG, Ostrander BEP, Blouch KL, Krolewski AS, Myers BD, et al. Detection of renal function decline in patients with diabetes and normal or elevated GFR by serial measurements of serum cystatin $C$ concentration: results of a 4-year follow-up study. J Am Soc Nephrol. 2005; 16:1404-1412.

4. Pavkov ME, Hanson RL, Lemley KV, Knowler WC, Williams DE, Myers BD, et al. Comparison of serum cystatin $C$, serum creatinine, measured GFR, and estimated GFR to assess the risk of kidney failure in American Indians with diabetic nephropathy. Am J Kidney Dis. 2013; 62(I):33-41.

5. Harmoinen APT, Kouri TT, Wirta OR, Lehtimaki TJ, Rantalaiho V, Turjanmaa $\mathrm{VMH}$, et al. Evaluation of plasma cystatin $\mathrm{C}$ as a marker for glomerular filtration rate in patients with type 2 diabetes. Clin Nephrol. 1999; 52:363-370.

6. Perlemoine C, Beauvieux MC, Rigalleau V, Baillet L, Barthes N, Derache $P$, et al. Interest of cystatin $C$ in screening diabetic patients for early impairement of renal function. Metabolism. 2003; 52:1258-1264.

7. Rule AD, Bergstrahl EJ, Slezak JM, Bergert J, Larson TS. Glomerular filtration rate estimated by cystatin $\mathrm{C}$ among different clinical presentations. Kidney Int. 2006; 69:399-405.

8. Thomas L, Huber AR. Renal function - estimation of glomerular filtration rate. Clin Chem Lab Med. 2006; 44:I295-I 302.

9. Tan GD, Lewis AV, James TJ, et al. Clinical usefulness of cystatin C for the estimation of glomerular filtration rate in type I diabetes. Reproducibility and accuracy compared with standard measures and iohexol clearance. Diabetes Care. 2002; 25:2004-2009.

10. Maclsaac RJ, Tsalamandris C, Thomas MC, et al. Estimating glomerular filtration rate in diabetes: a comparison of cystatin-C- and creatinine-based methods. Diabetologia. 2006; 49:1686- 1689.

II. Beauvieux MC, Le Moigne F, Lasseur C, Raffaitin C, Perlemoine C, Barthe $\mathrm{N}$, et al. New predictive equations improve monitoring of kidney function in patients with diabetes. Diabetes Care. 2007; 30: 1979-1987.

12. Rigalleau V, Raffaitin C, Gin H, Beauvieux MC, Le Moigne F, Lasseur $C$, et al. Accounting for body composition does not improve cystatin $C$ estimation of GFR in diabetic subjects with CKD. Am J Kidney Dis. 2007; 49:560.

13. Rigalleau V, Chauveau P, Beauvieux M-C, Gonzalez C, Raffaitin C, Lasseur $C$, et al. Estimation of renal function in patients with diabetes. Diabetes Metab. 201 I; 37:359-366.

14. Mussap M, Vestra MD, Fioretto P, Saller A, Varagnolo M, Nosadini R et al. Cystatin $C$ is a more sensitive marker than creatinine for the estimation of GFR in type 2 diabetic patients. Kidney Int. 2002; 61:|453-|46|.

15. Halimi J-M, Hadjadj S, Aboyans V, Allaert F-A, Artigou J-Y, Beaufils M, et al. Microalbuminurie et excrétion urinaire d'albumine: Recommandations pour la pratique clinique. Nephrol Ther. 2007; 3:384-391.

16. Tuttle KR, Bakris GL, Bilous RW, Chiang JL, de Boer $H$, GoldsteinFuchs J, et al. Diabetic kidney disease: a report from an ADA Consensus Conference. Diabetes Care. 2014; 37:2864-2883.

17. Haneda M, Utsunomiya K, Koya D, Babazono T, Moriya T, Makino H, et al. A new classification of diabetic nephropathy 2014: a report from Joint Committee on Diabetic Nephropathy. J Diabetes Investig. $2015 ; 6: 242-246$. 
18. Molitch ME, Steffes M, Sun W, Rutledge B, Cleary P, de Boer IH, et al. The development and progression of renal insufficiency with and without albuminuria in adults with type I diabetes mellitus in the Diabetes Control and Complications Trial (DCCT) and Epidemiology of Diabetes Interventions and Complications (EDIC) study. Diabetes Care. 2010; 33:1536-1543.

19. Agboton BL, Amoussou-Guenou D, Wanvoegbe A, Vigan J, Hazoume R, Agbodande A, et al. La microalbumurie chez les diabétiques de type 2 au sud du Bénin: fréquence de l'insuffisance rénale chronique précoce. J Soc Biol Clin du Benin. 20I5; 023:23-28.

20. Sobngwi E, Mbanya JC, Moukourie N, Nguk B. Microalbuminuria and retinopathy in a diabetic population of Cameroon. Diabetes Res Clin Pract. 1999; 44:191-196.

21. Ali AA, Al Lami FH. Prevalence and determinants of microalbuminurea among type 2 diabetes mellitus patients, Baghdad, Iraq, 20। 3. Saudi J Kidney Dis Transpl. 20I6; 27(2):348-355

22. Berrada S, Nassib M, Zamd M, Medkouri G, Hachim K., Benghamem $M$, et al. La prise en charge de la néphropathie diabétique. Diabetes Metab. 2009; 35(Suppl I): A34.

23. Ahmedani MY, Hydrie MZ, lqbal A, Gul A, Mirza WB, Basit A. Prevalence of microalbuminuria in type 2 diabetic patients in Karachi: Pakistan: A multi-center study. J Pak Med Assoc. 2005; 55:382-386.

24. Varghese A, Deepa R, Rema M, Mohan V. Prevalence of microalbuminuria in type 2 diabetes mellitus at a diabetes centre in Southern India. Postgrad Med J. 200 I; 77:399-402.

25. Ghosh S, Lyaruu I, Yeates K. Prevalence and factors associated with microalbuminuria in type 2 diabetic patients at a diabetes clinic in Northern Tanzania. Afr J Diabetes Med. 20I2; 20:43-46.

26. Aldukhayel A. Prevalence of diabetic nephropathy among Type 2 diabetic patients in some of the Arab countries. Int J Health Sci. 2017; II (I): 60-63.

27. Wasen E, Isoaho R, Mattila K, Vahlbergt, Kivela SI, Irjala K. Renal impairment associated with diabetes in the elderly. Diabetes Care. 2004; 27:2648-2653.

28. Oddoze C, Morange S, Portugal H, Berland $Y$ and Dussol B. Cystatin $C$ is not more sensitive than creatinine for detecting early renal impairment in patients with diabetes. Am J Kidney Dis. 200 I; 38(2):310-316.

29. Wang T, Wang $Q$, Wang Z, Xiao Z, Liu L. Diagnostic value of the combined measurement of serum Hcy, serum Cys $C$, and urinary microalbumin in type 2 diabetes mellitus with early complicating diabetic nephropathy. ISRN Endocrinol. 20I3;407452.

30. Mueller TF, Raeder J, Oettl K, Zitta S, Klausmann G, Estelberger W, et al. Cystatin $C$ does not detect acute changes in glomerular filtration rate in early diabetic nephropathy. Ren. Fail. 2008; 30(I):21-29. 